\title{
УЧЕТ ВЛИЯНИЯ АНИЗОТРОПИИ В ПРОЦЕССЕ ВЫПОЛНЕНИЯ ОБРАБОТКИ СЕЙСМИЧЕСКИХ ДАННЫХ ЗД ОРЕНБУРГСКОЙ ОБЛАСТИ.
}

Гречииникова Т.А., Лаптев Я.В.

В настоящее время в связи с наметившимся истошением традиционных нефтяных тровинций особенное значение в процессе выполнения сейсмогеологических исследований при разведке на нефть и газ приобретает выявление малоамплитудньх структур и литологических ловушек, что в свою очередь повышает требования к достоверности и качеству получаемых в процессе обработки данных. Одним из направлений, позволяющих в значительной степени повысить достоверность и информативность получаемьг данных, является учет влияния анизотропия в процессе выполнения обработки сейсмических данньгх.

В данной работе, на примере обработки $3 Д$ сеймических данных Оренбургской области (компании ТНК-ВР), рассматриваютея оба из основных видов анизотропии: VTI(вертикальная) и НТІ(горизонтальная) анизотропия. В докладе представлены: пример оценки VTI анизотропии и степень ее влияния на результаты оценок глубин в процессе выполнения глубинной миграции до суммирования и также оценка HTI анизотропии, этапы и результаты обработки данных $3 Д$ по четырем различным азимутам, полученным в 2005-2006 году на Горной птощади (Оренбургская область).

Основными задачами обработки являлись :

1. Оценка и учет влияния VTI анизотропия

2. Выявление наличия азимутальной анизотропии. Получение суммарных мигрированных кубов по различным азимутам, с целью последующего анализа трещиноватости;

3.Получение данных, пригодных для проведения AVO/AVA анализа продуктивных горизонтов.

На первом этапе, с использованием скважинных данных, был выявлен эффект значительной VTI анизотропики в верхней части разреза(рис 1).

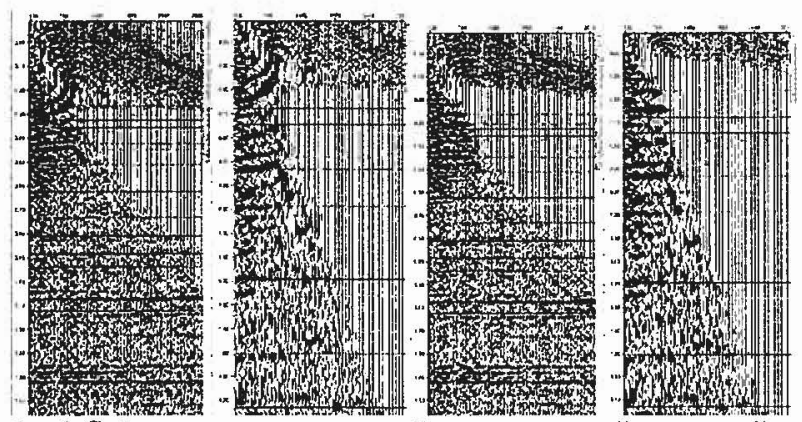

Рис. 1 Сейсмограммы с введенной кинематяческой поправкой до и после улета VTI анизотропии.

На втором этапе проводилась работа по изучению распространения горизонтальной анизотропии. Была выполнена оценка пригодности данных для изучения азимутальной анизотропии; на основе оценок подборок сейсмограмм были определены направления распространения преимущественно 'быстрых' и 'медленных' скоростей; сейсмичечские данные были разбиты на четыре группы- с разными направлениями прихода луча, по каждой из которых была выполнена мхграция до суммирования и автоматическое определение кинематической поправки в каждой точке ОСТ. Ниже представлены поля скоростей (рис 3) и карты амплитуд(рис 2) по одному из целевых горизонтов по двум разным азимутам, на которых видно изменение данных характеристик в зависимости от выбранных азимутов.

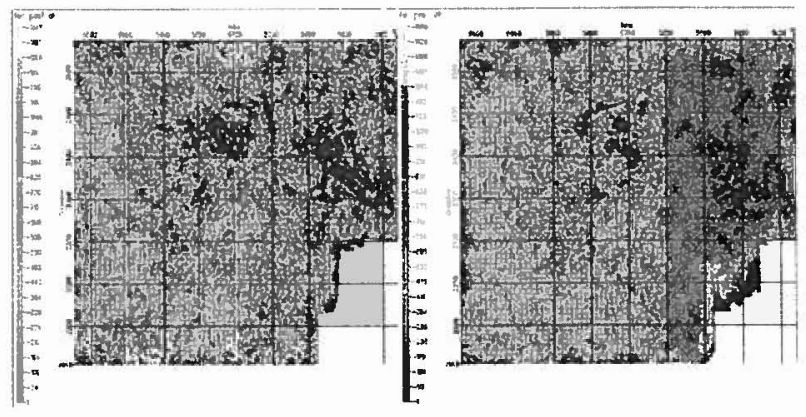

Рис. 2 Карты амплитуд разных азимутов

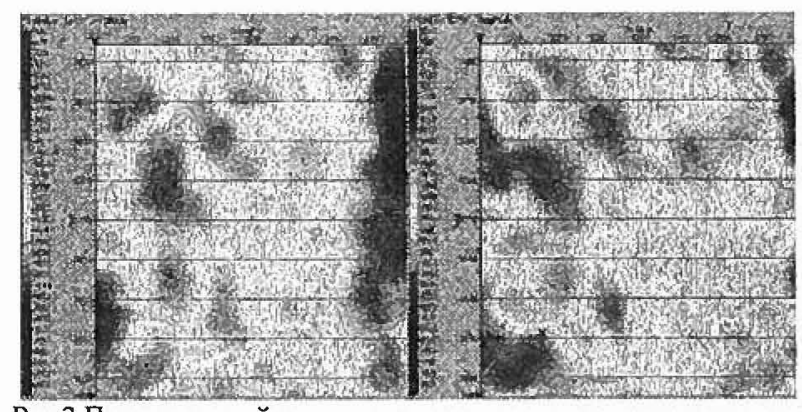

Рис.3 Поля скоростей разных азимутов

В настоящее время работа с данным проектом продолжкается- данные переданы в группу интерпретации. Одним из результатов этапа интерпретагии будет являтся карта распределения трещиноватости, полученная на основе изучения изменения амплитуд и скоростных полей кубов данных разных азимутов. 